\title{
Predicting stand damage and tree survival in burned forests in Catalonia (North-East Spain)
}

\author{
José Ramón GonzÁlez ${ }^{a *}$, Antoni Trasobares ${ }^{\mathrm{b}}$, Marc Palahía $^{\mathrm{a}}$, Timo PUKKala ${ }^{\mathrm{b}}$ \\ ${ }^{\text {a }}$ Centre Tecnològic Forestal de Catalunya. Pujada del seminari s/n, 25280 Solsona, Spain \\ ${ }^{\mathrm{b}}$ ForEcoTechnologies, Av. Diagonal 416, Estudio 2, Barcelona 08037, Spain
}

(Received 4 October 2006; accepted 13 March 2007)

\begin{abstract}
The study developed models for predicting the post-fire tree survival in Catalonia. The models are appropriate for forest planning purposes. Two types of models were developed: a stand-level model to predict the degree of damage caused by a forest fire, and tree-level models to predict the probability of a tree to survive a forest fire. The models were based on forest inventory and fire data. The inventory data on forest stands were obtained from the second (1989-1990) and third (2000-2001) Spanish national forest inventories, and the fire data consisted of the perimeters of forest fires larger than 20 ha that occurred in Catalonia between the 2nd and 3rd measurement of the inventory plots. The models were based on easily measurable forest characteristics, and they permit the forest manager to predict the effect of stand structure and species composition on the expected damage. According to the stand level fire damage model, the relative damage decreases when the stand basal area or mean tree diameter increases. Conversely, the relative stand damage increases when there is a large variation in tree size, when the stand is located on a steep slope, and when it is dominated by pine. According to the tree level survival models, trees in stands with a high basal area, a large mean tree size and a small variability in tree diameters have a high survival probability. Large trees in dominant positions have the highest probability of surviving a fire. Another result of the study is the exceptionally good post-fire survival ability of Pinus pinea and Quercus suber.
\end{abstract}

damage model / fire management / logistic function / tree mortality / survival model

Résumé - Prédiction des dommages au peuplement et de la survie des arbres dans les forêts brûlées en Catalogne. L'étude développe des modèles pour prédire la survie des arbres après feu en Catalogne. Les modèles sont appropriés à des objectifs de planification en forêt. Deux types de modèles ont été développés : un modèle au niveau des peuplements pour prédire le niveau des dommages causés par les feux de forêts, et des modèles arbre-centrés pour prédire la probabilité de survie à un feu de forêt. Les modèles sont basés sur les données de l'inventaire des forêts et des feux. Les données de l'inventaire des peuplements forestiers ont été obtenues à partir du deuxième (1989-1990) et du troisième (2000-2001) inventaire forestier espagnol, et les données sur les feux proviennent de périmètres de feux de forêts supérieurs à 20 ha qui se sont produits en Catalogne entre les deuxièmes et troisièmes mesures dans les placettes d'inventaire. Les modèles sont basés sur des caractéristiques facilement mesurables, et permettent au praticien forestier de prédire l'effet de la structure du peuplement et de la composition en espèces sur les dégâts. D'après le modèle de dommage au niveau peuplement, les dégâts diminuent lorsque la surface terrière ou le diamètre moyen des arbres augmente. Inversement, les dégâts augmentent en cas de forte variabilité de dimension des arbres, quand le peuplement est localisé sur une pente forte ou quand il est principalement composé de pins. Selon les modèles de survie arbre-centrés, les arbres de peuplements à forte surface terrière, forte dimension moyenne des arbres et faible variabilité des diamètres, présente la plus forte probabilité de survie au feu. Les grands arbres dominants présentent la plus forte probabilité de survivre au feu. Un autre résultat de cette étude est l'exceptionnelle capacité de survie après feu de Pinus pinea et Quercus suber.

modèle de dommage / gestion du feu / fonction logistique / mortalité des arbres / modèle de survie

\section{INTRODUCTION}

Mediterranean forests are affected by recurrent fire events, which cause significant economic damage [40]. Fire is the most common cause of tree mortality in the Mediterranean basin [3]. Therefore, the inclusion of fire risk analysis in the forest planning process is clearly justified. Such analyses help to reduce the uncertainty by anticipating the outcomes of management alternatives in a systematic way [12], and identifying management options that reduce the expected losses due to fire.

The analysis of fire risk in forest management planning requires a model for assessing the potential damage caused by

*Corresponding author: jr.gonzalez@ctfc.es fires. Models that predict the losses as a result of fire must be based on predictors whose future value is known with reasonable accuracy. If a model is to be used for forest planning purposes, it also has to consider variables that are under the control of the manager; this enables the manager to minimise the expected losses as a management objective in numerical planning calculations.

The variables driving the behaviour of wildland fires are normally grouped into climatic, topographic and fuel related variables. Among these, only fuel can be controlled [41]. Variables related to the aboveground vegetation such as stand density, species composition, vertical structure of the canopy, tree size and hierarchical position of the trees are all known, controllable and related to fuels. They are therefore useful 
predictors in damage models that are used in forest planning systems.

Previous studies have revealed relationships between structural variables of stands and the likelihood of fire damage (e.g. [2, 9, 30, 31, 39]). For example, Pollet and Omi [31] and Agee and Skinner [2] concluded that open stands of large trees with a small amount of ground fuel are less susceptible of suffering severe fire damage. The relationships between tree size and post-fire tree mortality has also been widely studied (e.g. [5, $18,22,24,26,32,34])$, and the general consensus is that larger trees are less likely to die in a fire.

According to Fowler and Sieg [11], most of the studies dealing with fire damage can be divided in two categories, the ones using tree tissue damage to predict tree mortality after fire, and others using fire behaviour parameters such as fire intensity as predicting variables. Unfortunately, tree tissue damage and fire intensity are seldom known in planning. The use of fire behaviour simulators to predict the damage presents serious limitations over large spatial and temporal domains $[10,33]$. This is because they require information on weather conditions and fuel accumulation which are difficult to predict over long periods of time and across large heterogeneous landscapes [17]. This implies that many of the existing post-fire mortality models have little use in forest planning, the purpose of which is to predict the long-term consequences of management alternatives. Another important limitation of the available models is the relatively small number of forest types that they cover; most of the models can be applied only to even-aged coniferous stands although in reality stands may be even-aged or uneven-aged, and the species composition may vary.

The aim of the present study is to develop stand-level damage models and post-fire tree survival models appropriate for forest planning purposes and scenario analyses in Catalonia. The models should use variables that are easily measurable in forest inventories or otherwise available in planning. The models should be able to predict the potential damage caused by fire in any forest stand in Catalonia, depending on the site and the structure of the stand. In addition to predicting the degree of damage at the stand level, the models should also identify the survivors when the damage is not total. This is required in simulators that use individual trees as the smallest calculation unit.

To meet these aims, two types of models were developed: a stand-level model for the degree of damage caused by a forest fire, and tree-level models for the probability of a tree to survive a forest fire

\section{MATERIALS AND METHODS}

\subsection{Inventory plots}

The modelling data included inventory data and fire occurrence data. The data on forest stands were obtained from the second and third Spanish National Forest Inventory (IFN) in Catalonia $[8,20]$. The IFN data consisted of a systematic sample of permanent plots, distributed on a square grid of $1 \mathrm{~km}$, with a re-measurement interval of approximately 11 years. The following data were recorded for each
Table I. Number of observations $(N)$, observed survival probability (Survival), and mean proportion of dead trees (Damage) in the stands for the eight most common tree species and the whole study material (Total). "Baseline" is the mean survival probability in non-burned inventory plots.

\begin{tabular}{|c|c|c|c|c|c|c|c|}
\hline & \multicolumn{3}{|c|}{ Tree level data } & \multicolumn{4}{|c|}{ Stand level data } \\
\hline & $N$ & urviv & 3aseline & $\bar{N}$ & $\overline{\text { Damag }}$ & tanda & Range \\
\hline & 574 & 0.74 & 0.959 & 23 & 0.32 & 0.34 & $0-1$ \\
\hline Pinus pinea & 280 & 0.92 & 0.979 & 16 & 0.18 & 0.35 & $0-1$ \\
\hline Pinus halepensis & 2201 & 0.50 & 0.966 & 286 & 0.45 & 0.46 & $0-1$ \\
\hline Pinus nigra & 4741 & 0.67 & 0.979 & 276 & 0.42 & 0.41 & $0-1$ \\
\hline Pinus pinaster & 106 & 0.55 & 0.988 & 5 & 0.40 & 0.55 & $0-1$ \\
\hline Quercus faginea & 240 & 0.48 & 0.978 & 7 & 0.11 & 0.29 & $0-0.77$ \\
\hline Quercus ilex & 552 & 0.62 & 0.979 & 41 & 0.19 & 0.38 & $0-1$ \\
\hline Quercus suber & 628 & 0.94 & 0.974 & 35 & 0.11 & 0.21 & $0-1$ \\
\hline Other sp. & 276 & 0.67 & 0.970 & 33 & 0.07 & 0.25 & $0-1$ \\
\hline Total & 9598 & 0.65 & 0.964 & 722 & 0.38 & 0.43 & $0-1$ \\
\hline
\end{tabular}

sample tree: species, dbh, height, survival, and distance and azimuth from the plot centre. This resulted in 6229 survivors and 3369 dead trees, out of a total of 9598 trees inventoried in burned plots (Tab. I). Information about the abundance, mean height, and species composition of small trees $(\mathrm{dbh}<7.5 \mathrm{~cm})$ and bushes was also collected.

The 2nd and 3rd IFN in Catalonia took place during the periods 1989 to 1990 (2nd) and 2000 to 2001 (3rd), and covered a surface area of $32114 \mathrm{~km}^{2}$. The IFN inventory plots represented 52 different forest types in Catalonia. The elevation of the plots ranged from sea level up to over $2300 \mathrm{~m}$. Of the 10855 inventory plots that were measured over the whole of Catalonia (Fig. 1), all plots which were located within the perimeters of forest fires that took place between the two inventories were used in this study ( 722 plots).

\subsection{Fire data}

The fire data consisted of the perimeters of forest fires larger than 20 ha (Fig. 1) that occurred in Catalonia after the 2nd IFN measurement and prior to the 3rd IFN measurement (i.e., the fires between 1989 and 2001). In the case of fires that occurred in the same year as one of the IFN measurements, the exact dates of the fire event and of the IFN measurement were used to find out whether the fire had occurred between the two measurements. The fire data included 4944 burned areas, corresponding to 150 fires, with a total area of 146023 ha.

The fire perimeters were determined on the 1:50 000 scale map by the Department de Medi Ambient i Habitatge and the Institut Cartográfic de Catalunya as follows. The information of the fire reports (date of the fire, initiation coordinates, estimated burned area, etc.) was compared to images of burned areas (LANDSAT, SPOT, CASI or ortophotos). For each fire, a file was created with geo-referenced data from the affected area, both before and after the fire. The data were processed to estimate the effect of fire on the vegetation cover, using the Normalized Difference Vegetation Index (NDVI) [37] and principal components analysis. Digital classification was used for delineating the fire perimeter. A posterior control phase allowed a more accurate differentiation of the burned and unburned areas. 


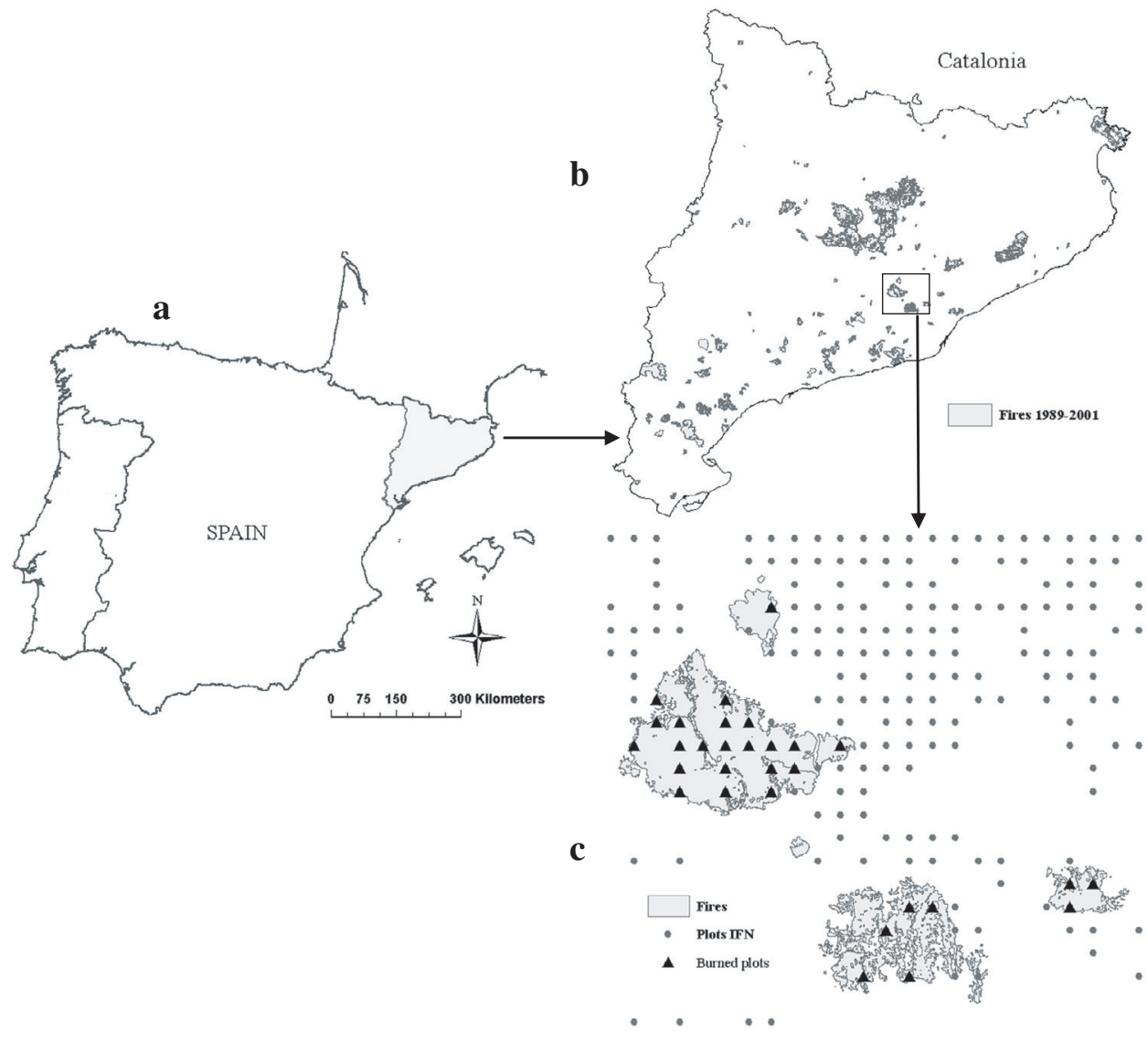

Figure 1. Location of Catalonia (a), forest fires occurred in the study area during 1989-2001 (b), and a part of the national forest inventory (IFN) plots used in the study (triangles in map c).

\subsection{Data preparation}

After collecting the IFN and fire perimeter data, the next step was to separate the plots of the IFN for Catalonia which were burned between the two IFN measurements. The data showed that 722 out of 10855 IFN plots had been burned. To obtain this information, spatial layers from both sets of data (IFN plots and fire perimeters) were overlaid using GIS tools [4]. From this map, the IFN plots within fire perimeters were classified as plots that were burned (Fig. 1). A comparison of the number of fires (4944) and number of burned inventory plots (722) reveals that there were many burned areas in which there was no inventory plot. The variable that was used to describe the damage at the stand level was the proportion of trees that died as a result of fire (Tab. I).

\subsection{Stand-level damage modelling}

A stand-level fire damage model was developed by testing a number of stand-level variables related to the structure, composition and location of the stands as predictors. All predictors had to be significant at the 0.05 level without any systematic errors in the residuals. The predicted variable $(y)$ was the logit transformation of the proportion of dead trees:

$$
y=\ln \left(\frac{p}{1-p}\right)
$$

where $p=\left\{\begin{array}{l}0.01 \text { if } P_{\text {dead }} \leqslant 0.01 \\ P_{\text {dead }} \text { if } 0.01<P_{\text {dead }}<0.99 \text {, } \\ 0.99 \text { if } P_{\text {dead }} \geqslant 0.99\end{array}\right.$
$P_{\text {dead }}$ is the observed proportion of dead trees. The logit transformation forces the prediction to be within zero and one. The model was estimated using the ordinary least squares (OLS) method in the SPSS statistical program [36]. The model described the linear relationship between the logit transformation of the degree of damage (proportion of dead trees) and the selected stand-level predictors (Tab. II).

\subsection{Modelling post-fire tree survival}

The logistic function was used to model tree survival since it is mathematically flexible, easy to use, and has a meaningful interpretation [19]. Several models predicting the probability of a single tree to survive or to die have been developed using logistic regression methods $[5,7,16,18,22,24,25,29,32,38]$.

Two different models were developed using the Binary Logistic procedure in SPSS [36]. The first one used ordinary site, tree and stand variables as predictors, whereas the second one used the degree of damage and tree size (diameter at breast height) as the only predictors. The predictors were selected taking into account three criteria. Firstly, log-likelihood ratio tests were used to determine whether the addition of a variable improved the model significantly. Secondly, the importance of the variable in terms of forest inventory and management, as well as its simplicity, was considered. Finally, the effect of adding the variable on the odds ratio of the variables already in the model was calculated. The odds for an event are defined as the probability that the event occurs divided by the probability that the event 
Table II. Descriptive statistics for the variables used as predictors in the damage and survival models ( $N$ is number of observations).

\begin{tabular}{|c|c|c|c|c|c|}
\hline Variable & $N$ & Minimum & Maximum & Mean & Standard deviation \\
\hline \multicolumn{6}{|l|}{ Stand-level predictors } \\
\hline Basal-area-weighted mean diameter, $D_{g}(\mathrm{~cm})$ & 722 & 8 & 42 & 18.83 & 4.448 \\
\hline Quadratic mean diameter, $D_{q}(\mathrm{~cm})$ & 722 & 0 & 43 & 14.22 & 7.255 \\
\hline Stand basal area, $G\left(\mathrm{~m}^{2} \mathrm{ha}^{-1}\right)$ & 722 & 0 & 59 & 17.22 & 8.865 \\
\hline Slope $(\%)$ & 722 & 2 & 42 & 33.33 & 11.320 \\
\hline Pine-dominated stand, Pine & 722 & 0 & 1 & 0.84 & 0.370 \\
\hline Standard deviation of diameter, $s_{d}(\mathrm{~cm})$ & 722 & 0 & 15 & 4.91 & 1.761 \\
\hline \multicolumn{6}{|l|}{ Tree-level predictors } \\
\hline Diameter, $d(\mathrm{~cm})$ & 9598 & 8 & 68 & 18.35 & 7.050 \\
\hline Basal area of trees larger than the subject tree, $B A L\left(\mathrm{~m}^{2} \mathrm{ha}^{-1}\right)$ & 9598 & 0 & 59 & 8.56 & 7.084 \\
\hline
\end{tabular}

does not occur [21]. The odds ratio quantifies how many times more (or less) the event is likely to occur at the known levels of the predictors. Due to interactions between some variables in the models, the odds ratios were computed by exponentiating the algebraic difference between the logits at two levels of the variable considered. In this way, the odds ratios for different units of change could be analyzed [19].

\section{RESULTS}

\subsection{Stand damage model}

The stand-level damage model had the following form:

$$
\begin{aligned}
& y=b_{0}+b_{1} G+b_{2} \text { Slope }+b_{3} \text { Pine }+ \\
& \qquad b_{4}\left(\frac{G}{D_{q}+0.01}\right)+b_{5}\left(\frac{s_{d}}{D_{q}+0.01}\right)+e
\end{aligned}
$$

where $y=\ln \left(P_{\text {dead }} /\left(1-P_{\text {dead }}\right)\right), P_{\text {dead }}$ is the proportion of dead trees in the stand (in terms of number of trees), $G$ is the stand basal area $\left(\mathrm{m}^{2} \mathrm{ha}^{-1}\right)$, Slope is the percentage of altitude change per distance change (\%), Pine is a dummy variable which equals 1 if the stand is dominated by pines ( $>50 \%$ of basal area is pine) and 0 otherwise, $s_{d}$ is the standard deviation of the breast height diameters of trees $(\mathrm{cm}), D_{q}$ is the quadratic mean diameter $(\mathrm{cm})$ of trees, and $e$ is the standard deviation of the residual (standard error). The predictor $G /\left(D_{q}+0.01\right)$ is non-linearly related to the number of trees per hectare. The last predictor $s_{d} /\left(D_{q}+0.01\right)$ expresses the relative variability of tree diameters. The variable is close to 1 in rather uneven stands and approaches to 0 in homogeneous stands.

All the variables included in the stand damage model were significant at the 0.05 level (Tab. III). The coefficient of determination $\left(R^{2}\right)$ was 0.173 , the bias was 0 , and the standard error was 3.434 for the logit (116\% of the mean of predicted values if calculated in the original units). According to the model, the proportion of dead trees decreases when stand basal area increases (Fig. 2). Higher values of $G /\left(D_{q}+0.01\right)$ and $s_{d} /\left(D_{q}+0.01\right)$ increase the damage. The other two factors that contribute to a high fire damage are steep slopes and pine dominance (Fig. 2). Condition indices [36] were calculated for all the predictors and they showed no significant multicollinearity. All the condition indices were less than 20.
Table III. Regression coefficients and level of significance of the stand level damage model variables (Eq. (2)).

\begin{tabular}{lcccc}
\hline Effect & Variable & Coefficient & S.E. & Significance \\
\hline$b_{0}$ & Intercept & -6.131 & 0.555 & 0.000 \\
$b_{1}$ & $G$ & -0.329 & 0.051 & 0.000 \\
$b_{2}$ & Slope & 0.060 & 0.012 & 0.000 \\
$b_{3}$ & Pine & 2.266 & 0.354 & 0.000 \\
$b_{4}$ & $G /\left(D_{q}+0.01\right)$ & 4.319 & 0.725 & 0.000 \\
$b_{5}$ & $s_{d} /\left(D_{q}+0.01\right)$ & 6.718 & 1.121 & 0.000 \\
\hline
\end{tabular}

\subsection{Tree survival models}

Two different models were developed to predict the probability of a single tree surviving a wildfire event. One used tree and stand characteristics as predictors (Eq. (3)), while the other one was based on tree size and the stand-level degree of fire damage (Eq. (4)). The models are as follows:

$$
\begin{aligned}
& P_{\text {sur }}^{1}=\left(1+e^{-\left(b_{0}+b_{1} d+b_{2} B A L+b_{3} D_{g}+b_{4} G+b_{5}\left(\frac{s_{d}}{D_{g}+0.01}\right)+b_{6} \text { PPinea }+b_{7} Q S \text { uber }\right)}\right)^{-1} \\
& P_{\text {sur }}^{2}=\left(1+e^{-\left(b_{0}+b_{1} d+b_{2} P_{\text {dead }}\right)}\right)^{-1}
\end{aligned}
$$

where $P_{\text {sur }}$ is the probability of survival, $d$ is the diameter of the tree at the breast height $(\mathrm{cm}), B A L$ is the basal area of trees larger than the subject tree $\left(\mathrm{m}^{2} \mathrm{ha}^{-1}\right), D_{g}$ is the basal-areaweighted mean diameter $(\mathrm{cm})$ of trees, $G$ is the total basal area of the stand $\left(\mathrm{m}^{2} \mathrm{ha}^{-1}\right), s_{d}$ is the standard deviation of breast height diameter $(\mathrm{cm})$, PPinea and QSuber are dummy variables indicating whether the tree is Pinus pinea or Quercus suber (if the tree is $P$. pinea, PPinea equals 1 and if it is $Q$. suber, $Q$ Suber equals 1 , and 0 otherwise), and $P_{\text {dead }}$ is the proportion of dead trees.

The variables included in the first model (Eq. (3)) represent, on one hand, the size and position of the tree in the diameter distribution ( $d$ and $B A L)$, and the structure of the stand $\left(D_{g}\right.$, $s_{d} /\left(D_{g}+0.01\right)$ and $\left.G\right)$, on the other hand. Variables PPinea and QSuber represent the special behaviour (high survival rate) of two tree species with respect to fire (see Tab. I). For the second survival model (Eq. (4)), in which the stand level degree of damage $\left(P_{\text {dead }}\right)$ was used as a predictor, the only other significant predictor was the tree $\mathrm{dbh}$. 
a

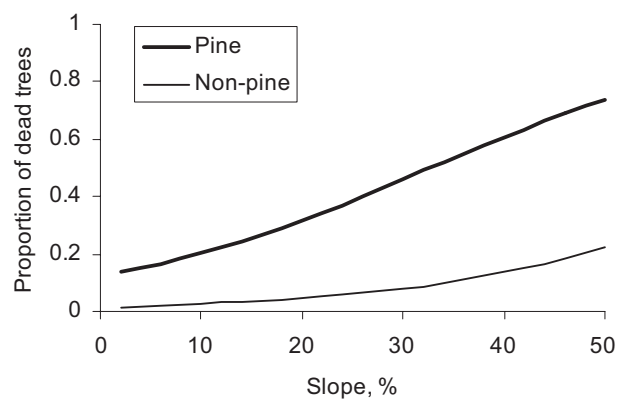

C

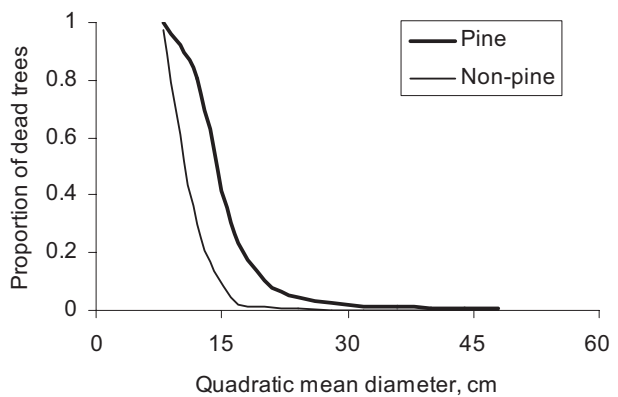

b

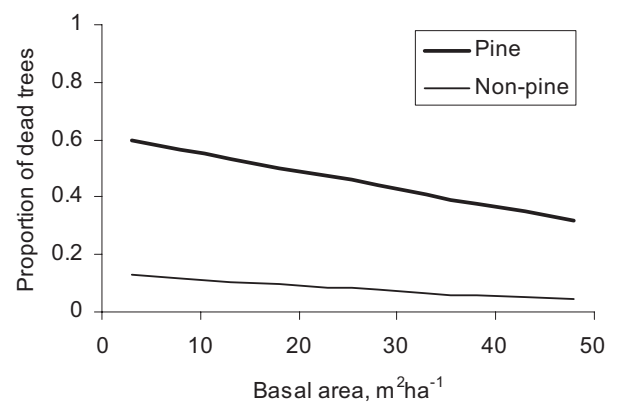

d

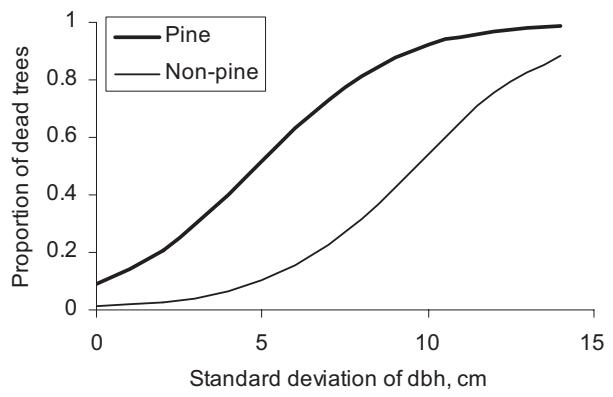

Figure 2. Effect of slope (a), stand basal area (b), quadratic mean diameter (c), and standard deviation of diameter (d) on the proportion of dead trees according to Equation (2). Variables other than the one on the $\times$ axis are equal to their mean value in the modelling data (Tab. II).

Several other variables were also tested representing site factors (latitude, aspect and continentality), stand structure and species composition (amount of bushes, small trees and species groups), and variables related to fire behaviour such as the size of the burned area within which the plot was located. However, the best fits were obtained with Equations (3) and (4).

The Nagelkerke $R^{2}$ [36] was 0.165 for Equation (3) and 0.788 for Equation (4). According to condition indices, there was no significant multicollinearity the variables in the models. All variables included in the models (Tab. IV) were significant according to the Wald test [36] $(p<0.05)$. According to Equation (3), larger diameters and trees in dominant positions (low $B A L$ value) have higher probability of surviving a fire (Fig. 3). Furthermore, trees in forest stands with higher values of $G$ and $D_{g}$, but with low variability of stand diameters $\left(s_{d} /\left(D_{g}+0.01\right)\right)$ have also higher survival probabilities (Fig. 3). The first survival model also shows that $P$. pinea and $Q$. suber trees have better post-fire survival ability. According to the second survival model, large trees in stands with low expected damage are the most likely to survive (Fig. 4).

There are three different ways to use the survival models in simulations. One is to multiply the frequencies of trees by their predicted survival probability. The other ways are suitable for individual tree simulators, in which a decision must be taken whether or not a particular tree dies. The stochastic way uses Monte Carlo simulation, which compares the predicted survival probability to a uniform random number. If stochasticity is not wanted, a threshold must be specified for the survival probability beyond which the tree is taken as a survivor. To analyse the behaviour of the models in this kind of determinis- tic simulation, the so-called receiving operating characteristic (ROC) curves [35] we calculated for the models by gradually changing the threshold probability from zero to one, and with every threshold calculating the numbers of predicted survivals and dead trees, separately for observed survivors and observed dead trees (Fig. 5). The relative area below an ROC curve is a measure on accuracy, and its range is from 0.5 (chance) and 1.0 (perfect). The relative area below the ROC curve was 0.844 for Equation (4) when used with observed stand level damage and 0.677 when Equation (4) was used with predicted damage. For Equation (3) the relative area was slightly smaller, 0.673, which means that the combined use of Equations (2) and (4) gives slightly better results than the use Equation (3). The best threshold probability was 0.5 for both Equation (3) and the combination of Equations (2) and (4) (Fig. 6), i.e., a tree should be taken as a survivor when its predicted survival probability is 0.5 or more. If the stand-level degree of damage is known, the best threshold probability is 0.3 .

The odds ratios of the predictors were computed by exponentiating the algebraic difference between the logits at two levels of the predictor (Tab. V). Changes in $D_{g}$ and $s_{d}$ had a clear effect on the survival probability in Equation (3), but the effect was not constant across different values. In the case of $s_{d}$ the odds ratio depended on the value of $D_{g}$; the same change in $s_{d}$ had a much smaller effect on survival when $D_{g}$ was $10 \mathrm{~cm}$ than when it was $30 \mathrm{~cm}$. Similarly, the effect of a change in $D_{g}$ depended on the value of $s_{d}$. Other variables whose change led to big changes in survival probability were PPinea and $Q$ suber; the survival probabilities were around four times higher if the tree was $P$. pinea or $Q$. suber. For the three remaining variables $(d, B A L, G)$, a change of ten units altered 

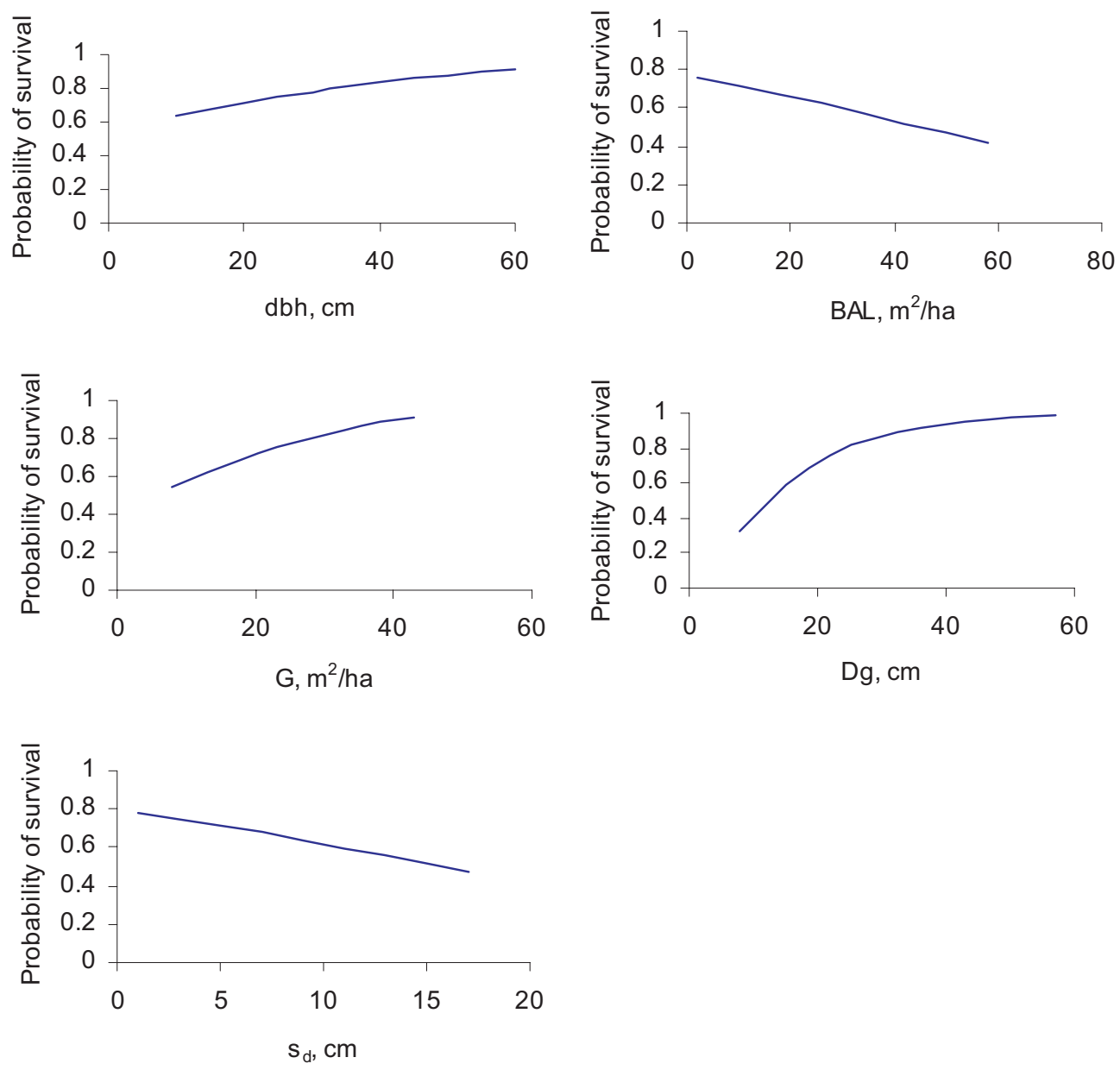

Figure 3. Effect of tree diameter (dbh), basal area of larger trees (BAL), total basal area $(\mathrm{G})$, basal-area-weighted mean diameter (Dg) and standard deviation of $\mathrm{dbh}\left(\mathrm{s}_{d}\right)$ on the survival probability of a tree, according to Equation (3) for species other than $P$. pinea and $Q$. suber.
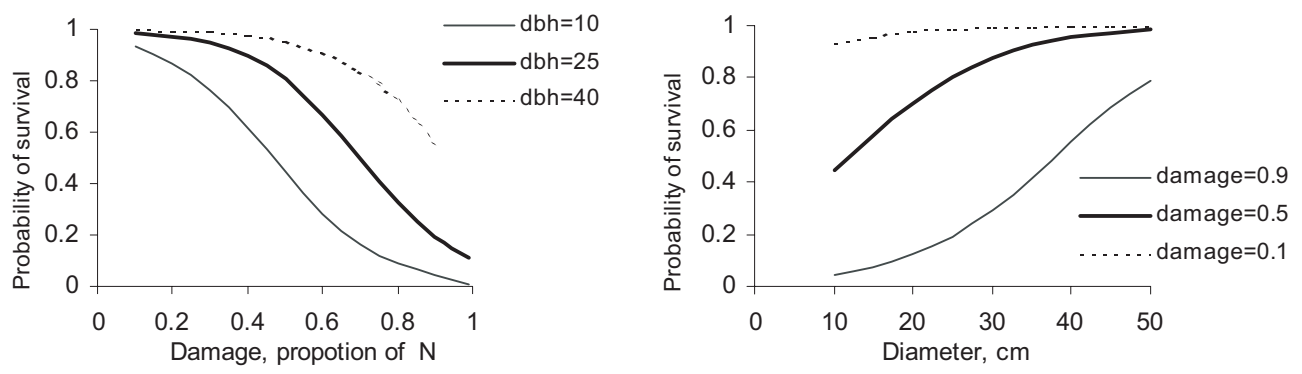

Figure 4. Effect of the degree of fire damage (proportion of dead trees, $P_{\text {dead }}$ ) and tree diameter (dbh) on the survival probability of a tree, according to Equation (4).

the survival probability by $1.3-1.85$ times. In Equation (4), variations in both $d$ and $P_{\text {dead }}$ caused a major change in the survival probability.

\subsection{An example of application}

To evaluate the effect of stand structure on the potential post-fire damage, the models were applied to four hypothetical forest stands. The analysed stands had the same location (slope) and species composition (all trees were pines but not $P$. pinea), but different size distributions of trees. In a mature even-aged stand, the survival probability of all trees was high (Fig. 7A) and the predicted damage was low (Fig. 8), which can be explained by the absence of small trees, a high basal area, and a small variability in tree size (no fuel ladder effect). In the young even-aged stand, the probability of the tree's survival was relatively small (Fig. 7B) and the predicted damage high, mainly because of the small size of the trees. The 


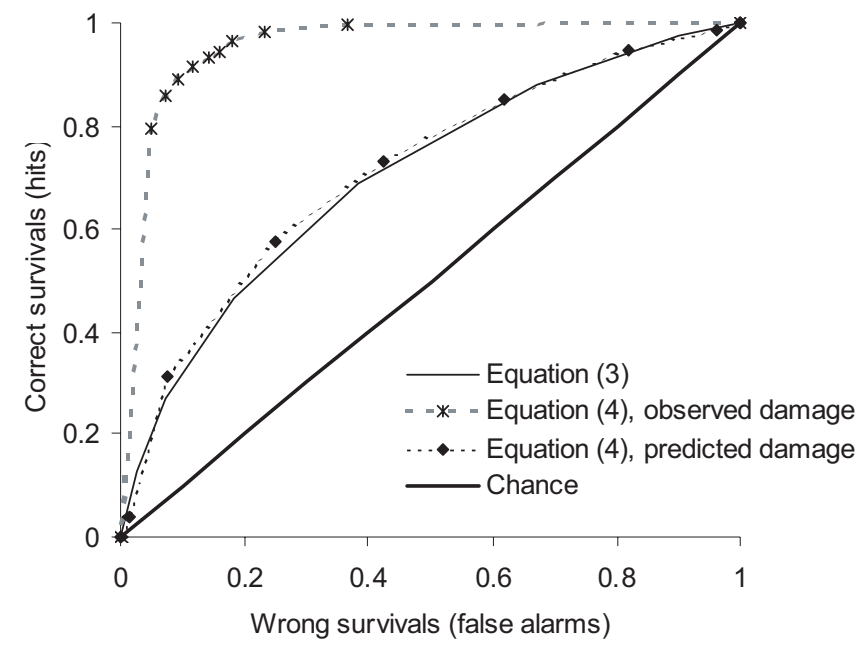

Figure 5. Receiver operating characteristic curves for Equation (3) and for Equation (4) when used with predicted or observed stand level damage. A high area between the $\times$ axis and the curve implies high accuracy.

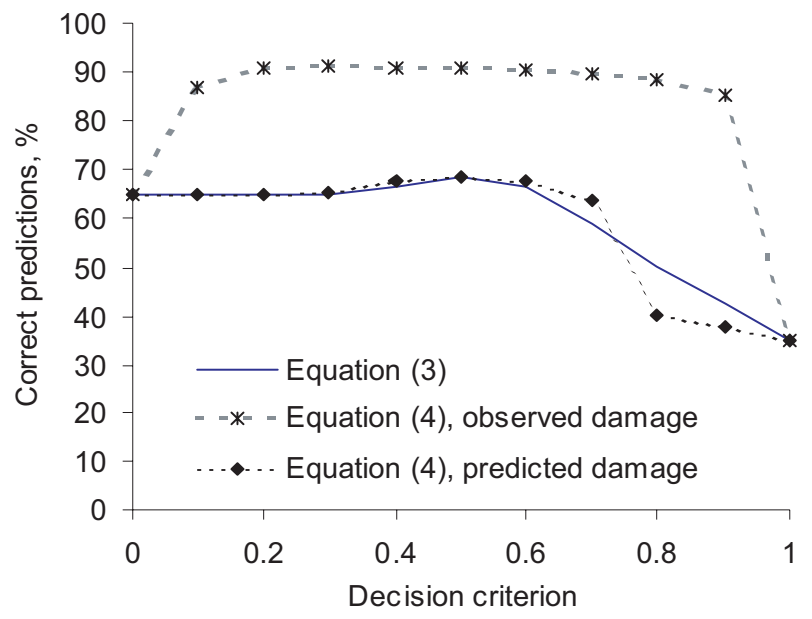

Figure 6. Percentage of correct predictions as a function of predicted survival probability that classifies trees as survivors (decision criterion).

two-layered stand (Fig. 7C) had a reasonably high survival probabilities for the top layer trees $(>18 \mathrm{~cm})$ but much smaller for the low layer trees. The predicted degree of damage was significantly higher than in the case of the mature even-aged stand (Fig. 8). The uneven-aged stand had a rather low survival probability for small trees, but the survival probability increased with tree diameter. This tendency was more pronounced when the stand-level degree of damage was used to predict tree survival (Fig. 7D).

\section{DISCUSSION}

The presented damage and survival models were based on variables available with standard forest inventories or easily
Table IV. Regression coefficients values, standard deviations (S.E.) and statistical significance for the tree survival models described in Equations (3) and (4).

\begin{tabular}{lccccc}
\hline Effect & Variable & Coefficient & S.E. & Wald statistic & Significance \\
\hline$b_{0}$ & Intercept & -2.035 & 0.145 & 196.7 & 0.000 \\
$b_{1}$ & $d$ & 0.036 & 0.007 & 24.5 & 0.000 \\
$b_{2}$ & $B A L$ & -0.026 & 0.008 & 11.4 & 0.001 \\
$b_{3}$ & $D_{g}$ & 0.084 & 0.009 & 89.6 & 0.000 \\
$b_{4}$ & $G$ & 0.062 & 0.005 & 150.1 & 0.000 \\
$b_{5}$ & $s_{d} /\left(D_{g}+0.01\right)$ & -1.722 & 0.470 & 13.4 & 0.000 \\
$b_{6}$ & $P$ Pinea & 1.299 & 0.212 & 37.7 & 0.000 \\
$b_{7}$ & $Q$ Suber & 1.431 & 0.136 & 110.2 & 0.000 \\
\hline \multicolumn{5}{c}{ Equation (4) } \\
\hline$b_{0}$ & Intercept & 2.224 & 0.123 & 325.1 \\
$b_{1}$ & $d$ & 0.110 & 0.006 & 293.1 & 0.000 \\
$b_{2}$ & $P_{\text {dead }}$ & -7.117 & 0.135 & 2788.5 & 0.000 \\
\hline \multicolumn{5}{c}{} \\
\hline
\end{tabular}

Table V. Odds ratios for the predictors of Equations (3) and (4). The values of the unchanged variables are set equal to their mean values in the study material unless indicated otherwise.

\begin{tabular}{lccc}
\hline Variable & Unit & Change in the variable & $\begin{array}{c}\text { Increase in survival } \\
\text { probability }\end{array}$ \\
\hline \multicolumn{4}{c}{ Equation (3) } \\
\hline$d$ & $\mathrm{~cm}$ & From 20 to 30 & Increases 1.43 times \\
$B A L$ & $\mathrm{~m}^{2} \mathrm{ha}^{-1}$ & 15 to 5 & 1.30 \\
$G$ & $\mathrm{~m}^{2} \mathrm{ha}^{-1}$ & 20 to 30 & 1.86 \\
$D_{g}, s_{d}=5$ & $\mathrm{~cm}$ & 20 to 30 & 2.67 \\
$D_{g}, s_{d}=15$ & $\mathrm{~cm}$ & 20 to 30 & 3.56 \\
$s_{d}, D_{g}=10$ & $\mathrm{~cm}$ & 15 to 5 & 5.60 \\
$s_{d}, D_{g}=30$ & $\mathrm{~cm}$ & 15 to 5 & 1.77 \\
$P$ Pinea & - & 0 to 1 & 3.67 \\
QSuber & - & 0 to 1 \\
\hline \multicolumn{5}{c}{ Equation (4) } \\
\hline$d$ & $\mathrm{~cm}$ & 20 to 30 & Increases 3.00 times \\
$P_{\text {dead }}$ & - & 0.6 to 0.4 & 4.15 \\
\hline
\end{tabular}

derived from them. Damage and survival depended mainly on variables that can be changed through forest management. The study used a large dataset of forest stand plots and fires, with a broad spatial and temporal coverage. Therefore, the models allow the manager to predict the post-fire damage for a wide range of forest types under the current fire regime of Catalonia.

One way to use these models in forest planning calculations and scenario analyses is to generate fire occurrences with the earlier model of González et al. [15], after which the degree of damage can be predicted with the stand level model of this study (Eq. (2)). In simulators that use individual trees, the survivors can be selected using Equation (4). Another possibility in individual tree simulators is to use Equation (3) directly to select the survivors, after which the stand-level damage may be calculated as the proportion of dead trees. The first approach offers the possibility to generate more variation in stand-level results if a stochastic component corresponding to the residual variation of the stand level model is added to the prediction. If the whole range on variation in the degree of 

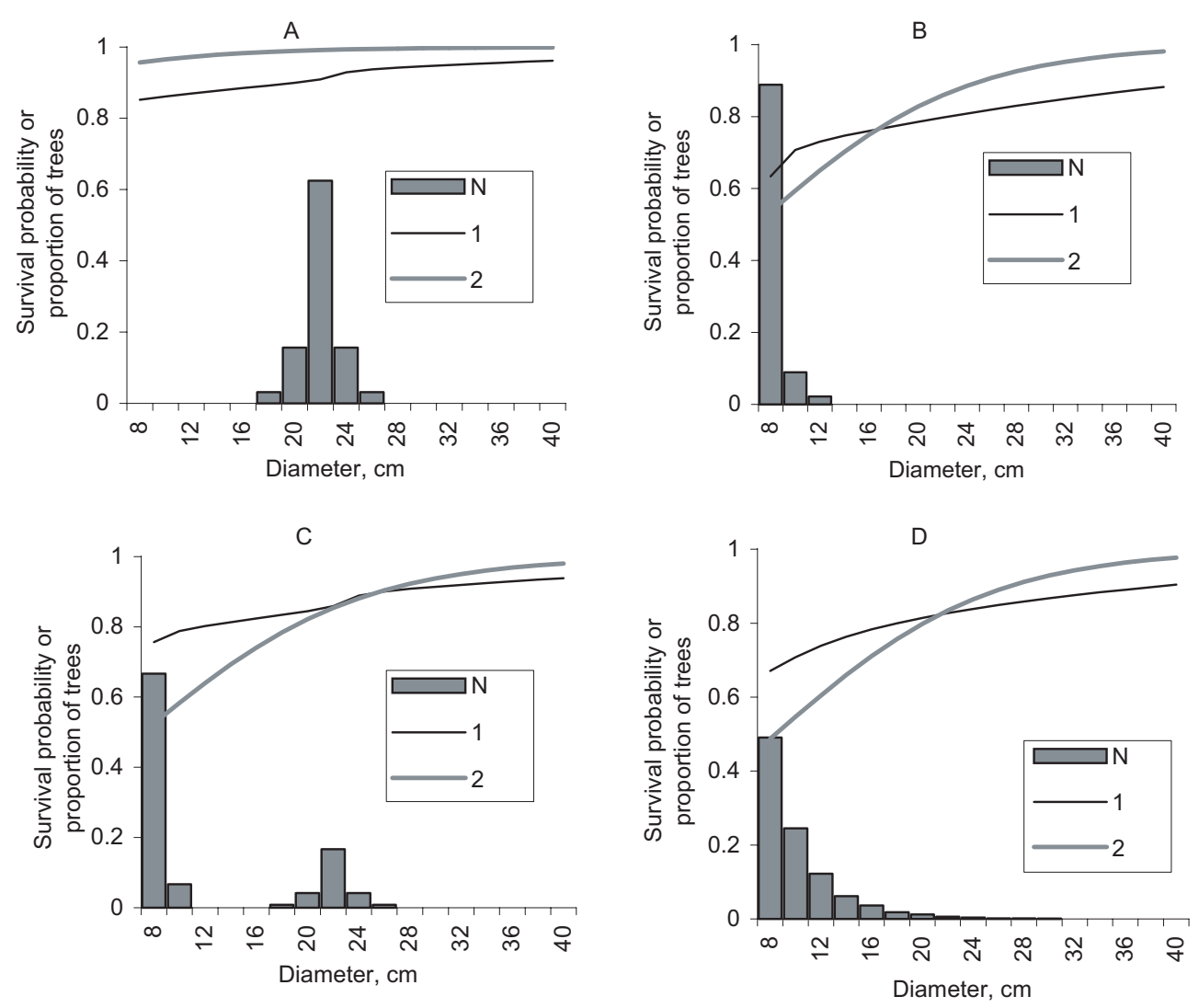

Figure 7. Survival probability and relative number of trees for different diameter classes in an even-aged mature (A), young even-aged (B), two-storied (C), and uneven-aged (D) pine stand that has been swept by fire. The survival probability has been calculated in two ways: (1) with a model in which the degree of damage is not a predictor (Eq. (3)), and (2) using a model (Eq. (4)) in which the predicted degree of damage (Eq. (2)) is used as a predictor. The slope of the terrain was 10 degrees.

damage should be mimicked in simulations, a stochastic use of the stand level model is then the correct way to use the models.

If stochastic simulation is not a reasonable option (when the best possible prediction is wanted to individual stands separately) the models can be used to calculate a "fire loss index" for the stands. The loss index is equal to the predicted probability of fire occurrence ([14]; their Eq. (1)) times the predicted degree of damage (Eq. (2) of this study). This index may be calculated for alternative stand management schedules. Then, in forest planning, minimisation of the loss index could be used as a criterion when selecting the best treatment schedules for the stands.

Compared with previous models for post-fire tree mortality, our models do not use tissue damage or fire severity as predictors, since those predictors are seldom available in the inventory data and they can not be predicted accurately in the future. However, some of the variables included in the models have a clear correlation with fire behaviour. For example, steeper slopes increase the expected damage, which may be explained by an easier transfer of heat uphill, through a possible "chimney" effect, and lower fuel moisture [1]. Species composition, defined in one model as pine vs. non-pine stand, was found to have an important effect on the damage, probably due to the high flammability of conifers [6]. Other variables used to

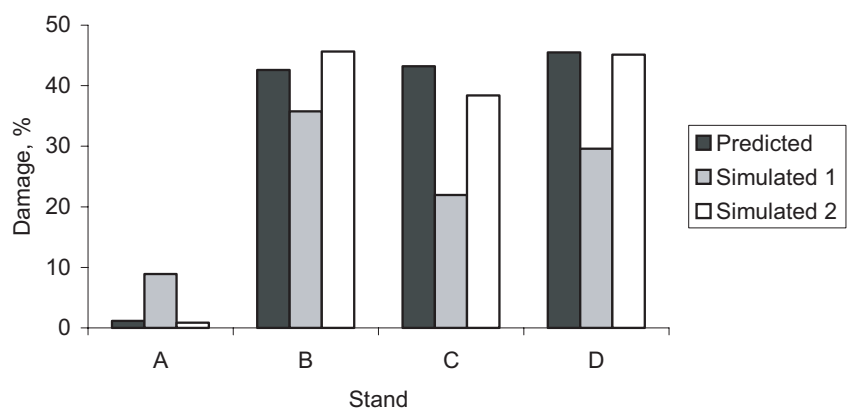

Figure 8. Predicted (Eq. (2)) and simulated damage for the same stands (A,B,C,D) as in Figure 6. The simulated damage is calculated using the survival probabilities of individual trees. Numbers 1 and 2 refer to the calculation method: method 1 uses survival function in which stand level damage is not a predictor (Eq. (3)) while method 2 uses a model (Eq. (4)) where the predicted stand level damage degree is a predictor.

describe stand structure had coefficients that were in accordance with studies that indicate that mature even-aged stands present a lower expected fire damage than multi-layered [31] and young even-aged stands. 
Apart from variables included in the models, many other variables related to site and stand characteristics were tested and rejected as predictors, even if their effect on fire behaviour has been universally accepted, such as elevation and the amount of ground vegetation. Elevation, which plays an important role in the fire occurrence probability $[15,23]$, did not correlate with the degree of damage in burned areas. This is because most of the burned stands were located in low elevations where temperature is high and moisture low. Elevation has a strong influence on fire occurrence [15], but not on the degree of damage in a burned forest.

The effect of ground vegetation on tree survival was not significant. This may be partly because ground vegetation could have changed significantly during the 11-years fire observation period [27], implying that the initial amount of bushes and small trees may not have described well enough the situation in the year of the fire event. Nevertheless, it may be assumed that the stand characteristics included in the models correlate with the amount and characteristics of ground vegetation, meaning that these variables were, to some degree, implicitly included in the model.

Other variables that are also often included in the models are fire size and time between the occurrence of fire and the plot measurement. These variables were carefully analysed, but did not improve the models. Even if the size of the fire can give some information about the particular weather conditions at the time of the fire, high variability in fire spreading conditions is a normal characteristic of large fires [26], reducing the possibilities of knowing the fire conditions prevailing in a given point within the burned area. Time since fire has also been reported to be an important variable for determining the post-fire tree mortality, with relevant differences between the results obtained from early measurements ( $<3$ years after fire) and those from later ones [34]. In our study, the plots that were burned less than three years prior to the 3rd IFN measurement did not indicate a survival level different from that of the other plots.

Tree diameter was found to be a significant predictor of tree survival, which is in accordance with previous studies $[18,22,32,34]$. The result may be explained by thicker bark and higher canopy normally observed in bigger trees, which prevents their more sensible tissues to be reached by the fire. The effect of the hierarchical position of the tree, included in one of the survival models through the $B A L$ variable, was also significant. This result agrees with the idea that tree mortality after fire may be caused not only by the short-term stress that the disturbance involves, but also by previous long-term stress [38], dominant trees having experienced less competition than smaller stress. In two cases, the probability of survival was found to be species-dependent, cork oak $(Q$. suber $)$ and stone pine ( $P$. pinea) being exceptionally fire tolerant. The high survival rate of cork oaks can be explained by its thick bark and re-sprouting capability [28]. In the case of stone pine, the long distance of the crown from the ground, its thick bark, and the intensive management (bush cleaning and pruning) of stone pine plantations, might be explanations for the good fire tolerance of this tree species.
The models developed for predicting tree survival allow for the quantification of the expected post-fire damage and identifying the trees most likely to survive. The models are based on empirical data, and they are management-oriented by nature as they enable the manager to quantify the effect of different management options on the expected fire damage. The characteristics of the models allow their use in numerous studies and applications, related with the integration of fire risk into forest management planning. For instance, they can be used together with fire probability models [15] in stand-level optimisation studies [13] and landscape level planning studies [14]. Another important use of the models is scenario analyses at a regional scale, which in Spanish conditions could be certainly biased if fires are omitted. In addition to removing biases, the models allow the analyst to compare different management policy alternatives with respect to the expected losses caused by forest fires.

The data used in this study and the variables included in the presented models were chosen so that the models could be used in forest management planning. It is not meaningful to compare our models with previous models which use tree tissue damage or fire intensity as predictors for estimating postfire mortality. This is because fire spreading conditions and tissue damages are not known in planning.

Acknowledgements: This study was financed by the MEDACTHU project from the MEDOCC Interreg IIIB programme and the EU EFORWOOD project. The authors want to thank the Juan de la Cierva and Torres Quevedo programs from the Spanish Ministry of science and education for supporting the work of two of the authors. The authors wish to thank also the members of the Servei de Prevenció d'Incendis Forestals de Catalonia for providing the fire data used in this study, and Mr. David Gritten for the linguistic revision of the manuscript. The study was conducted within the MEDFOREX program coordinated by the Forest Technology Centre of Catalonia.

\section{REFERENCES}

[1] Agee J.K., Fire ecology of Pacific Northwest forests, Island Press, Washington, DC, USA, 1993, 493 p.

[2] Agee J.K., Skinner C.N., Basic principles of forest fuel reduction treatments, For. Ecol. Manage. 211 (2005) 83-96.

[3] Alexandrian D., Esnault F., Calabri G., Forest fires in the Mediterranean area, Unasylva 197 (2000) 35-41.

[4] ArcGIS 9.0., ESRI, 2004.

[5] Beverly J.L., Martell D.L., Modeling Pinus strobus mortality following prescribed fire in Quetico Provincial Park, northwestern Ontario, Can. J. For. Res. 33 (2003) 740-751.

[6] Bond W.J., Van Wilgen B.W., Why and how do ecosystems burn? Fire and Plants, Chapman \& Hall, New York, 1996, pp. 17-33.

[7] Brown J.K., DeByle N.V., Fire damage, mortality, and suckering in aspen, Can. J. For. Res. 17 (1987) 1100-1109.

[8] DGCN, Tercer Inventario Forestal Nacional (1997-2007) Cataluña: Barcelona, Ministerio de Medio Ambiente, Madrid, 2005.

[9] Finney M.A., Modeling the spread and behaviour of prescribed natural fires, Proc. 12th Conf. Fire and Forest Meteorology, 1994, pp. 138-143. 
[10] Finney M.A., Mechanistic modeling of landscape fire patterns, in: Mladenoff D.J., Baker W.L., (Eds.), Spatial modeling of forest landscape change: approaches and applications, Cambridge University Press, Cambridge, UK, 1999, pp. 186-209.

[11] Fowler J.F., Sieg C.H., Postfire mortality of ponderosa pine and Douglas-fir: A review of methods to predict tree death, Gen. Tech. Rep. RMRS-GTR-132. Fort Collins, CO, US Department of Agriculture, Forest Service, Rocky Mountain Research Station, 2004, 25 p.

[12] Gadow K.v., Evaluating risk in forest planning models, Silva Fenn. 34 (2000) 181-191.

[13] González J.R., Pukkala T., Palahí M., Optimising the management of Pinus sylvestris L. stand under risk of fire in Catalonia (north-east of Spain), Ann. For. Sci. 62 (2005) 493-501

[14] González J.R., Palahí M., Pukkala T., Integrating fire risk considerations in forest management planning - a landscape level perspective, Landsc. Ecol. 20 (2005) 975-970.

[15] González J.R., Palahí M., Trasobares A., Pukkala T., A fire risk model for forest stands in Catalonia (north-east of Spain), Ann. For. Sci. 63 (2006) 169-176.

[16] Guinto D.F., House A.P.N., Xu Z.H., Saffigna P.G., Impacts of repeated fuel reduction burning on tree growth, mortality and recruitment in mixed species eucalypt forests of southeast Queensland, For. Ecol. Manage. 115 (1999) (1):13-27.

[17] He H.S., Mladenoff D.J., Spatially explicit and stochastic simulation of forest landscape fire disturbance and succession, Ecology 80 (1999) 81-99.

[18] Hély C., Flannigan M., Bergeron Y., Modeling tree mortality following wildfire in the southeastern Canadian mixed-wood boreal forest, For. Sci. 49 (2003) 566-576.

[19] Hosmer D.W., Lemeshow, S., Applied logistic regression, 2nd ed., Wiley Series in Probability and Mathematical Statistics, New York, 2000, $307 \mathrm{p}$.

[20] ICONA, Segundo Inventario Forestal Nacional (1986-1995), Cataluña: Barcelona, Madrid, 1993.

[21] Jalkanen A., Mattila U., Logistic regression models for wind and snow damage in northern Finland based on the National Forest Inventory data, For. Ecol. Manage. 135 (2000) 315-330.

[22] Linder P., Jonsson P., Niklasson M., Tree mortality after prescribed burning in an old-growth Scots pine forest in Northern Sweden, Silva Fenn. 32 (1998) 339-349.

[23] Martin R.E., Fire history and its role in succession. in: Means J.E. (Ed.), Forest succession and stand development research in the Northwest: Proceedings of a Symposium, USDA Forest Service Forest Research Laboratory, Oregon State University, Corvallis, Oregon, 1982, pp. 92-98.

[24] McHugh C.V., Kolb T.E., Ponderosa pine mortality following fire in northern Arizona, Int. J. Wildl Fire, 12 (2003) 7-22.
[25] Mutch L.S., Parsons D., Mixed conifer forest mortality and establishment before and after prescribed fire in Sequoia National Park, California, For. Sci. 44 (1998) 341-355.

[26] Ordóñez J.L., Retana J., Espelta J.M., Effects of tree size, crown damage, and tree location on post-fire survival and cone production of Pinus nigra trees, For. Ecol. Manage. 206 (2005) 109-117.

[27] Outcalt K.W., Wade D.D., Fuels management reduces tree mortality from wildfires in southeastern United States, J. Appl. For. 28 (2004) 28-34.

[28] Pausas J.G., Resprouting of Quercus suber in NE Spain after fire, J. Veg. Sci. 8 (1997) 703-706.

[29] Peterson D.L., Arbaugh M.J., Estimating postfire survival of Douglas-fir in the Cascade Range, Can. J. For. 19 (1989) 530-533.

[30] Peterson D.L., Johnson M.C., Agee J.K., Jain T.B., McKenzie D., Reinhard E.D., Forest structure and fire hazard in dry forests of the Western United States, Gen. Tech. Rep. PNW-GTR-628. Portland, OR, US Department of Agriculture, Forest Service, Pacific Northwest Research Station, 2005, 30 p.

[31] Pollet J., Omi P.N., Effect of thinning and prescribed burning on crown fire severity in ponderosa pine forests, Int. J. Wildl. Fire 11 (2002) 1-10.

[32] Rigolot E., Predicting postfire mortality of Pinus halepensis Mill. and Pinus pinea L., Plant Ecol. 171 (2004) 139-151.

[33] Rothermel R.C., Predicting behavior and size of crown fires in the northern Rocky Mountains, USDA Forest Service, Research Paper INT-483, Ogden, Utah, 1991.

[34] Ryan K.C., Reinhardt E.D., Predicting postfire mortality of seven western conifers, Can. J. For. Res. 18 (1988) 1291-1297.

[35] Saveland J.M., Neuenschwander L.F., A signal detection framework to evaluate models of tree mortality following fire damage, For. Sci. 36 (1990) 66-76.

[36] SPSS Inc., SPSS Base system syntax reference Guide, Release 9.0, 1999.

[37] Tucker C.J., Vanpraet C., Sharman M.J., Vanfnttersum G., Satellite remote sensing of total herbaceous biomass production in the Senegalese Sahel: 1980-1984, Remote Sens. Environ. 17 (1985) 233-249.

[38] Van Mantgem P.J., Stephenson N.L., Mutch L.S., Johnson V.G., Esperanza A.M., Parsons D.J., Growth rate predicts mortality of Abies concolor in both burned and unburned stands, Can. J. For. Res. 33 (2003) 1029-1038.

[39] Van Wagner C.E., Conditions for the start and spread of crown fire, Can. J. For. Res. 7 (1977) 23-34.

[40] Velez R., Mediterranean forest fires: A regional perspective, Unasylva 162 (1990) 10-12.

[41] Weatherspoon C.P., Skinner C.N., An assessment of factors associated with damage to tree crowns from the 1987 wildfires in northern California, For. Sci. 41 (1995) 430-451. 